\section{Leaf Abscission in Radermachera sinica in Response to Ethylene and Silver Thiosulfate}

\author{
Yin-Tung Wang ${ }^{1}$ and James R. Dunlap ${ }^{2}$ \\ Texas A\&M University Agricultural Research and Extension Center, \\ 2415 East Highway 83, Weslaco, TX 78596
}

Additional index words. foliage plant, postharvest handling

Radermackera sinica $\mathrm{L}$. is a deciduous tree native to southeastern Asia (Liu, 1972), having opposite bipinnate leaves with numerous green leaflets. Although $R$. sinica plants generally perform well in most indoor environments, rapid and near complete defoliation has occurred during shipping and retail distribution, possibly due to exposure to ethylene (Marousky and Harbaugh, 1979, 1982; Reid, 1985). Silver thiosulfate (STS) has been used to prevent ethylene-induced injuries (Reid et al., 1980; Reid, 1985). Our study determined the effect of ethylene on leaf drop and the protection offered by the application of STS to $R$. sinica.

Twenty-eight $R$. sinica seedlings grown in 1.5 -liter pots, and which received a single, foliar application of daminozide at 2500 $\mathrm{mg} \cdot$ liter $^{-1}$, were separated at random into seven groups and sprayed to runoff with 0 , $0.125,0.25,0.375,0.5,1.0$, or $4.0 \mathrm{mM}$ STS prepared as described, by Reid et al. (1980). Maximum photosynthetic photon flux (PPF) was $420 \mu \mathrm{mol} \cdot \mathrm{s}^{-1} \cdot \mathrm{m}^{-2}$. Air temperature at the time of STS application was 30C. Plants were evaluated for STS foliar injury on the uppermost pair of fully expanded leaves after 7 days.

To determine ethylene sensitivity, one pair of STS-treated leaves was taken below the youngest, fully expanded leaves. Only plants receiving STS treatments of 0 (control) or $0.125 \mathrm{~mm}$ were used to screen for sensitivity to ethylene-induced leaf abscission. Petioles with a full complement of leaflets were placed in individual flasks containing distilled water. Four flasks containing leaves from each STS treatment were placed in each of two Plexiglass chambers $\left(0.21 \mathrm{~m}^{3}\right)$ maintained at 25 $\pm 1 \mathrm{C}$ under continuous light providing a PPF of $15 \mu \mathrm{mol} \cdot \mathrm{s}^{-1} \cdot \mathrm{m}^{-2}$ from cool-white fluorescent tubes. Sufficient ethylene was injected into chambers to give concentrations of 0.5 and $2.0 \mathrm{ml} \cdot \mathrm{liter}^{-1}$. Flasks containing leaves were removed from the chambers after $24 \mathrm{hr}$ of exposure and placed on a laboratory bench. Leaves were examined at 2-hr inter-

Received for publication 29 Aug. 1988. The cost of publishing this paper was defrayed in part by the payment of page charges. Under postal regulations, this paper therefore must be hereby marked advertisement solely to indicate this fact.

'Assistant Professor.

${ }^{2}$ Associate Professor. Work conducted while employed by USDA-ARS, SARL, Weslaco, Texas. vals beginning $22 \mathrm{hr}$ after the ethylene treatment.

The application of $4.0 \mathrm{~mm}$ STS caused severe injury to all leaves, and treated plants became unsalable (Table 1). Leaves receiving STS between 0.375 and $1.0 \mathrm{~mm}$ showed various degrees of phytotoxicity, resulting in unmarketable plants. Although $0.25 \mathrm{~mm}$ STS induced some necrosis, plants were still salable due to the small number and size of lesions. No phytotoxicity was observed on plants treated with $0.125 \mathrm{~mm}$ STS.

Leaves unprotected with STS and exposed to $2.0 \mathrm{ml}$ ethylene/liter lost all leaflets within $22 \mathrm{hr}$, with abscission occurring in most of the petioles and rachises (Fig. 1). Similar leaves exposed to $0.5 \mathrm{ml}$ ethylene/liter for $24 \mathrm{hr}$ exhibited no abscission during the 24hr exposure to ethylene. However, leaf abscission had initiated within $4 \mathrm{hr}$ following removal from the chamber and was complete within $30 \mathrm{hr}$. Also, the degree of response to ethylene at $0.5 \mathrm{ml} \cdot$ liter $^{-1}$ was less severe, as evidenced by the intact petioles and rachises (Fig. 1). All leaflets on the STS-treated leaves at both ethylene concentrations remained intact during the next 30 days. Both types of experiments were repeated several times and results were consistent.

Ethylene-induced leaf abscission in $R$. sinica occurred at lower concentrations of ethylene and more rapidly than reported for other foliage plants (Marousky and Harbaugh, 1982; Reid, 1985). Although appli- cation of 4 mm STS may be safe on ornamental such as Brassaia actinophylla (Reid, 1985), much lower concentrations are required to avoid injury in $R$. sinica. Foliar application of STS at $0.125 \mathrm{~mm}$ to $R$. sinica seems to provide excellent protection against injurv from ethylene-contaminated environments encountered within commercial shipping and handling channels.

Table 1. Degree of leaf injury 7 days following foliar application of silver thiosulfate (STS) at various concentrations. Air temperature at the time of STS application was 30C.

\begin{tabular}{lcc}
\hline \hline $\begin{array}{c}\text { STS } \\
\text { concn } \\
(\mathrm{mM})\end{array}$ & $\begin{array}{c}\text { Leaflets with } \\
\text { lesions } \\
(\%)\end{array}$ & $\begin{array}{c}\text { Plant } \\
\text { grade } \\
(1-5)^{\mathrm{y}}\end{array}$ \\
\hline 0 (control) & $0 \pm 0$ & $5.0 \pm 0$ \\
0.125 & $0 \pm 0$ & $5.0 \pm 0$ \\
0.250 & $30 \pm 5$ & $4.0 \pm 0$ \\
0.375 & $48 \pm 9$ & $3.5 \pm 0.6$ \\
0.500 & $56 \pm 6$ & $2.5 \pm 0.6$ \\
1.0 & $75 \pm 8$ & $1.3 \pm 0.3$ \\
4.0 & $100 \pm 0$ & $1.0 \pm 0$ \\
\hline
\end{tabular}

${ }^{2}$ Means are the average of eight replicates $\pm \mathrm{sE}$ of the mean.

${ }^{y} 5$ = No foliar injury; 4 = slight injury, but salable; $3=$ moderate injury, salability doubtful; 2 = unmarketable; 1 = severe injury.

\section{Literature Cited}

Liu, Y.-C. 1972. Ligneous plants of Taiwan. Natl. Chung-Hsing Univ. Press, Taichung, Taiwan, Republic of China.

Marousky, F.J. and B.K. Harbaugh. 1979. Interactions of ethylene, temperature, light, and $\mathrm{CO}_{2}$ on leaf and stipule abscission and chlorosis in Philodendron scandens subsp. oxycardium. J. Amer. Soc. Hort. Sci. 104:876-880.

Marousky, F.J. and B.K. Harbaugh. 1982. Responses of certain flowering and foliage plants to exogenous ethylene. Proc. Fla. State Hort Soc. 95:159-162.

Reid, M.S. 1985. Ethylene and abscission. HortScience 20:45-50.

Reid, M. S., J.L. Paul, M.B. Farhoomand, A.M. Kofranek, and G.L. Staby. 1980. Pulse treatments with silver thiosulfate complex extend the vase life of cut carnations. J. Amer. Soc. Hort. Sci. 105:25-27.

Fig. 1. Leaves of Radermachera sinica without STS application $6 \mathrm{hr}$ after completion of a 24-hr treatment with 2 (right) or 0.5 (middle ) $\mathrm{ml}$ ethylene/liter. The leaf on the left received a foliar

spray of STS at $0.125 \mathrm{~mm}$ before exposure to $2 \mathrm{ml}$ ethylene/liter for $24 \mathrm{hr}$.

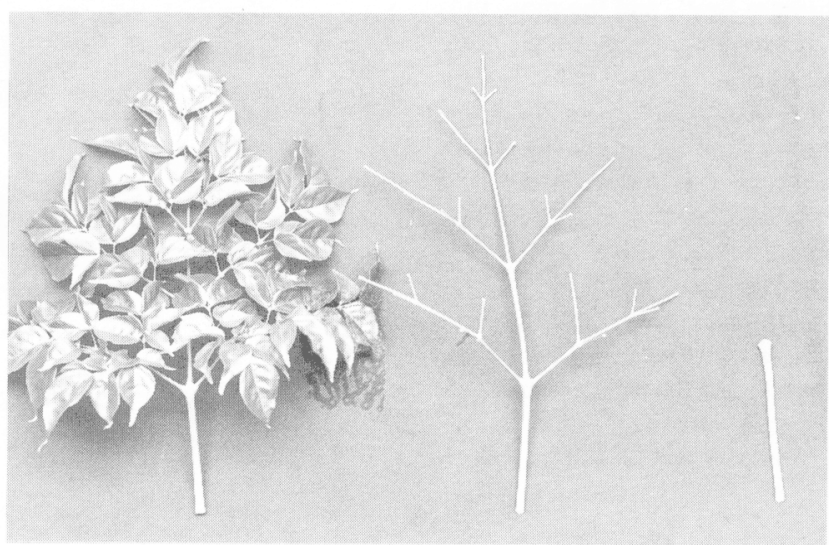

